УДК 1(031)+221

ЦЫРЕНОВ Чингис Цыбикдоржиевич - кандидат исторических наук, старший научный сотрудник отдела философии, религиоведения и культурологии Института монголоведения, буддологии и тибетологии СО РАН (670047, Россия, Республика Бурятия, г. Улан-Удэ, ул. Сахьяновой, 6; chts17@ mail.ru)

\title{
МОНАРХИ И КАНЦЛЕРЫ ЭПОХИ ВОСТОЧНАЯ ЦЗИНЬ (317-420 гг. Н.Э.) И РАННИЙ КИТАЙСКИЙ БУДДИЗМ
}

Аннотация. В статье проводится конкретно-исторический анализ событийной структуры, связанной с деятельностью придворных кланов династии Восточная Цзинь; кратко рассматриваются и анализируются сложные и малоизученные проблемы историко-политического процесса и истории раннего китайского буддизма смутной эпохи Восточная Цзинь. Автор делает вывод, что в период династии Восточная Цзинь произошел важный сдвиг в религиозно-идеологических предпочтениях южнокитайской элиты - от даосизма к китайскому буддизму.

Ключевые слова: Южный Китай, Восточная Цзинь (317-420 гг. н.э.), придворные кланы, ранний китайский буддизм

обытия конца III и начала IV в. нашей эры во многом повлияли на средневековую историю Китая, а опосредованно - и на историю соседних северных кочевых народов. Северокитайская империя Западная Цзинь (265317 гг. н.э.) провела ряд эффективных аграрных и экономических реформ, что позволило ей подчинить своей власти всю южнокитайскую территорию. Но в силу сочетания внутренних и внешних этнокультурных и геополитических факторов объективного и субъективного характера она вновь распалась на отдельные государственные образования. Иными словами, западноцзиньская империя оказалась сшитой на скорую руку и слабую нитку. Остатки правящего дома Сыма обосновались за широкой и могучей южнокитайской рекой Янцзы и назвали новую династию Восточная Цзинь (317-420 гг. н.э.). Можно сказать, что это новое государство было рыхлым осколком такой же рыхлой, эфемерной общекитайской империи Западная Цзинь. В 417 г. н.э., т.е. на излете династии Восточная Цзинь, площадь этой империи составляла около 3,02 млн Кв. км ${ }^{1}$. Это примерно соответствует территории современной Республики Саха (Якутия) - 3,084 млн кв. км. В периоды крестьянских народных восстаний и мятежей региональных магнатов площадь несколько сокращалась, и ее можно сравнить с территорией Красноярского края - 2,34 млн кв. км.

Что касается численности населения империи Восточная Цзинь, то в начале $\mathrm{V}$ в. нашей эры оно насчитывало около 17,46 млн чел. ${ }^{2}$ На основе этих данных можно приблизительно вычислить среднюю плотность населения империи начале V в. нашей эры $-5,45$ чел. на кв. км ${ }^{3}$. Очевидно, что это очень низкий показатель, его можно сравнить со средней плотностью населения, проживающего в настоящее время в Республике Казахстан (6,82 чел. на кв. км).

\footnotetext{
1 Восточная Цзинь. - Энциклопедия Байду. Доступ: https://baike.baidu.com/ item/\%Е4\%B8\%9С\%Е6\%99\%8В (проверено 24.02.2020).

2 Восточная Цзинь. - Энциклопедия Байду. Доступ: https://baike.baidu.com/item/\%E4\%B8\%9C\%Е $6 \% 99 \% 8 \mathrm{~B} / 456028$ ?fromtitle $=\% \mathrm{E} 4 \% \mathrm{~B} 8 \% 9 \mathrm{C} \% \mathrm{E} 6 \% 99 \% 8 \mathrm{~B} \% \mathrm{E} 5 \% \mathrm{~B} 8 \% 9 \mathrm{D} \% \mathrm{E} 5 \% 9 \mathrm{~B} \% \mathrm{BD} \&$ fromid $=7099061$ (проверено 24.02.2020).

3 Республика Казахстан. - Большая российская энциклопедия. Доступ: https://bigenc.ru/geography/ text/2032993 (проверено 24.02.2020).
} 
Иными словами, с известной долей условности можно сказать, что современная Республика Казахстан почти полностью соответствует империи Восточная Цзинь по площади своей территории, численности и средней плотности населения.

Среди отечественных историков-китаеведов, прямо или косвенно затронувших период династии Восточная Цзинь, необходимо назвать коллективную монографию М.В. Крюкова, В.В. Малявина и М.В. Софронова, работы М.Е. Ермакова, М.Е. Кравцовой, а также коллективную монографию О.Е. Непомнина и Н.А. Иванова [Крюков, Малявин, Софронов 1979: 19-25; Ермаков 1987; 1994: 188-207; Хуэй-цзяо 1991; 2005; Кравцова 2014: 111-124; Непомнин, Иванов 2010: 214-222]. В западной научной литературе историю и культуру данного периода изучали В. Либенталь, Э. Цюрхер, Р. Робинсон и Кеннет Чэнь [Liebenthal 1950; Zürcher 2007: 110-154; Robinson 1976: 96-115; Kenneth 1966: 110-115] и др. В китайской научной исторической литературе периодом династии Восточная Цзинь занимались Ван Чжунло, Тан Юнтун, Тянь Юйцин [Wang Zhongluo 2003: 296-353; Tang Yongtong 2011: 88-152; Tian Yongtong 2000: 296-353] и др. Несмотря на большое число работ по данной тематике в отечественной и зарубежной научной литературе, существует настоятельная необходимость в систематизации основных сведений о смутном периоде империи Восточная Цзинь.

Актуальность проблем, затронутых в статье, обусловлена тем, что без выявления и анализа конкретно-исторических факторов успешной реставрации бывшей общекитайской династии Цзинь в виде южнокитайской империи Восточная Цзинь невозможно в полной мере реконструировать важнейший кризисный и решающий этап раннесредневековой китайской государственности и культуры. Восточная Цзинь оказала глубочайшее влияние на развитие методов управления всех последующих региональных и всекитайских империй. Новизна исследования заключается в авторских переводах биографических данных высших сановников из жизнеописаний династийной хроники «Цзинь шу» («История династии Цзинь»), не переведенных на европейские языки.

В данной статье представлены результаты анализа исторических сведений о первом канцлере империи Восточная Цзинь по имени Ван Дао и его могущественном клане в контексте распространения китайского буддизма в среде китайской аристократии. В традиционной китайской историографии общепризнано, что административный гений канцлера Ван Дао внес решающий и колоссальный вклад в реставрацию правящего дома Сыма в Южном Китае и организацию нового государственного аппарата династии Цзинь. При решении этого сложного, многогранного и многоаспектного вопроса, по нашему мнению, необходимо обратиться к историко-биографическому и историко-географическому методам. В соответствующей словарной статье терминологического словаря «Теория и методология исторической науки» приводится следующее определение: «Историко-биографический метод - метод исторического исследования, направленный на описание, реконструкцию и анализ обстоятельств жизни, результатов деятельности, психологического портрета исторической личности/социальной группы. Историко-биографический метод известен давно, с ним связано становление и развитие истории как науки, поскольку основным героем политической истории всегда выступала личность - правитель, герой, военачальник и пр. С позиций этого подхода исторический процесс долгое время рассматривался как результат деятельности великих людей»1.

1 Мазур Л.Н. Историко-биографический метод. - Теория и методология исторической науки: терминологический словарь (отв. ред. А.О. Чубарьян). М.: Аквилон. 2014. С. 151-152. 


\section{Таблица 1}

\section{Периодизация эпохи Восточная Цзинь}

\begin{tabular}{|c|c|}
\hline Императоры & Ведущие кланы и фактические правители \\
\hline $\begin{array}{l}\text { 1. Юань-ди } \\
\text { (годы жизни 276-323, } \\
\text { годы правления 318-323) } \\
\text { 2. Мин-ди } \\
\text { (годы жизни 299-326, } \\
\text { годы правления 322-326) }\end{array}$ & $\begin{array}{l}310-325 \text { гг. } \\
\text { Северный клан братьев Ван: } \\
\text { Канцлер Ван Дао (276-339 гг.) и генерал-узурпатор Ван } \\
\text { Дунь (266-324 гг.) } \\
\text { Первая волна переселенцев с Севера }\end{array}$ \\
\hline $\begin{array}{l}\text { 3. Чэн-ди } \\
\text { (годы жизни } 321-342, \\
\text { годы правления 326-342) } \\
\text { 4. Кан-ди } \\
\text { (годы жизни } 322-345, \\
\text { годы правления 343-345) }\end{array}$ & $\begin{array}{l}325-345 \text { гг. н.э. } \\
\text { Северные кланы: Юй Лян (289-340); Юй Бин (296-344); } \\
\text { Цай Мо (281-356) } \\
\text { Южные кланы: Хэ Чун (292-346); Се Гуан (?-?); Фэн } \\
\text { Хуай (?-?); Чжу Ся (275-341); Чжу Гэхуэй (284-345) }\end{array}$ \\
\hline $\begin{array}{l}\text { 5. Му-ди } \\
\text { (годы жизни } 343-361, \\
\text { годы правления 344-361) } \\
\text { 6. Ай-ди (годы жизни } \\
341-365 \text {, годы правления } \\
\text { 361-365) }\end{array}$ & $\begin{array}{l}345-346 \text { гг. н.э. } \\
\text { Южнокитайский аристократ Хэ Чун прервал монополию } \\
\text { клана Юй и поддержал южные худородные помещичьи } \\
\text { кланы Хуань и Чу } \\
\text { Вторая волна переселенцев с Севера }\end{array}$ \\
\hline $\begin{array}{l}\text { 6. Фэй-ди } \\
\text { (годы жизни } 342-386, \\
\text { годы правления 365-371) }\end{array}$ & $\begin{array}{l}346-373 \text { гг. н.э. } \\
\text { Южный помещичий даосский клан Хуань во главе с } \\
\text { удачливым генералом Хуань Вэнем (312-373). }\end{array}$ \\
\hline $\begin{array}{l}\text { 7. Цзяньвэнь-ди } \\
\text { (годы жизни } 320-372, \\
\text { годы правления } 371-372 \text { ) }\end{array}$ & $\begin{array}{l}373-385 \text { гг. н.э. } \\
\text { Южный знатный клан Се во главе с генералом Се Анем } \\
(320-385 \text { гг.). }\end{array}$ \\
\hline $\begin{array}{l}\text { 8. Сяо У-ди } \\
\text { (годы жизни 362-396, } \\
\text { годы правления 372-396) }\end{array}$ & $\begin{array}{l}385-403 \text { гг. н.э. } \\
\text { Сам монарх Сяо У-ди и его брат - Сыма Даоцзы (364- } \\
403 \text { гг.) против южнокитайского клана генерала Хуань } \\
\text { Сюаня }\end{array}$ \\
\hline \multirow{2}{*}{$\begin{array}{l}\text { 9. Ань-ди } \\
\text { (годы жизни 397-418, } \\
\text { годы правления 396-418) }\end{array}$} & $\begin{array}{l}403-404 \text { гг. н.э. } \\
\text { Южнокитайский генерал Хуань Сюань и его неудачный } \\
\text { мятеж с попыткой основать коренную южную династию } \\
\text { Чу (402-403). }\end{array}$ \\
\hline & $\begin{array}{l}404-420 \text { гг. н.э. } \\
\text { Южный военно-плебейский клан Лю во главе с } \\
\text { генералом Лю Юем. }\end{array}$ \\
\hline
\end{tabular}

В дополнение к приведенной периодизации (см. табл. 1) следует сказать, что уже на первом этапе среди сторонников буддизма был северокитайский знатный клан Ван, которому династия Восточная Цзинь была обязана своей реставрацией в Южном Китае. Высший сановник-северянин Ван Дао, бывший потомственный адепт даосизма, перешел в буддийскую веру. Он возвысил высокообразованного чужеземного монаха-переводчика Шримитру (ок. 260-343 гг.), стал его учеником и ввел его в элитные круги Цзянькана. Более того, младший кузен сановника Ван Дао по имени Ван Даоцянь (286-374 гг. н.э.) стал буддийским монахом в 17-летнем возрасте (303 г.) и взял фамилию Чжу (Чжу Даоцянь). Иными словами, постепенное приобщение клана Ван к буддийскому вероучению началось еще до крушения всекитайской династии Западная Цзинь.

В 340 г. всесильный временщик-конфуцианец Юй Бин, глава северного слу- 
жилого конфуцианского клана, инициировал первую дискуссию, в которой поставил под сомнение автономный статус буддийского сообщества империи Восточная Цзинь. Можно предположить, что дата первой антибуддийской дискуссии связана со смертью канцлера Ван Дао, известного сторонника и покровителя буддизма при дворе династии Восточная Цзинь.

Победу в данной полемике одержали сановники-буддисты. Примечательно, что до начала полемики целый ряд придворных монахов, таких как Чжу Фашэнь (320-387), Чжи Дунь (314-366), и др. под давлением властей покинули столицу империи Восточная Цзинь и перебрались в приморскую местность столичной области Гуйцзи (район проживания сановников-аристократов), где основали новый центр южного буддизма.

В эпоху династии Восточная Цзинь и при следующих южных династиях буддийское духовенство располагало колоссальными финансовыми и земельными ресурсами, полученными от правящего класса. Борьба между кланами и группировками велась за высшие посты в том или ином министерстве центрального аппарата империи Восточная Цзинь.

Династия Восточная Цзинь и правящий дом Сыма постепенно утратили свои ведущие позиции в стране, а реальная власть перешла в руки внешних северных и южных придворных кланов. При этом многие пришлые и местные знатные кланы постепенно переходили из лона даосизма в буддийскую веру. При последующих южных династиях буддийские религиозно-философские идеи стали важной частью духовной жизни значительной части китайской элиты и потеснили даосизм и конфуцианство. Многие представители сановных кланов (Ван, Хэ, Се, Чжу и др.) становились потомственными буддистами-мирянами. Но вместе с тем на уровне большой политики даосские, буддийские и конфуцианские культы служили идеологическим орудием придворных группировок в борьбе за ключевые посты и ресурсы южнокитайской империи. Последние были основой для защиты и продвижения своих узкокорыстных сословно-клановых интересов. В такой исторической ситуации была заложена основа для формирования концепции трех учений (сань цзяо), которую активно использовали императоры последующих династий в интересах монархов и имперской бюрократии. Все это позволяет охарактеризовать данную династию как псевдомонархию, или военно-монархическую диктатуру.

Статья выполнена в рамках государственного задания (проект ХII.191.1.3. «Комплексное исследование религиознофилософских, историко-культурных, социально-политических аспектов буддизма в традиционных и современныхконтекстах России и стран Центральной и Восточной Азии», номер госрегистрации № АAАA-А17-117021310263-7).

\section{Список литературы}

Ермаков М.Е. 1987. Буддийский деятель в представлении официального китайского историографа (по материалам «Цзинь шу» и «Гао сэн чжуань»). Буддизм и государство на Дальнем Востоке: сборник статей. М.: Наука. С. 109129.

Ермаков М.Е. 1994. Мир китайского буддизма. СПб: Андреев и сыновья. 240 с. Кравцова М.Е. 2014. Династия Восточная Цзинь (317-420 гг. н.э.). - История Китая с древнейших времен до начала ХХІ века. В 10 т. Т. 3. Троецарствие, Цзинь, Южные и Северные династии, Суй, Тан (220-907). М.: Наука. 991 с.

Крюков М.В., Малявин В.В., Софронов М.В. 1979. Китайский этнос на пороге средних веков. М.: Наука. 328 с. 
Непомнин О.Е., Иванов Н.А. 2010. Типология азиатских обществ. М.: Восточная литература. $440 \mathrm{c.}$

Хуэй-цзяо. 1991. Жизнеописания достойных монахов [Гао сэн чжмуань] (пер. с кит., исслед., коммент. и указ. М.Е. Ермакова). В 3 т. Т. I (Раздел 1: Переводчики); отв. ред. Л.Н. Меньшиков). М.: Наука, ГРВЛ. 251 с.

Хуэй-цзяо. 2005. Жизнеописания достойных монахов [Гао сэн чжсуань] (пер. с кит., исслед., коммент. и указ. М.Е. Ермакова). В 3 т. Т. ІІ (Раздел 2: Толкователи). СПб.: Петербургское востоковедение. 240 с.

Kenneth K.S. 1966. Ch'en Buddhism in China A Historical Survey. Princeton: Princeton University Press. 576 p.

Liebenthal W. 1950. Shih Huiyuan's Buddhism as Set Forth in his Writings. - Journal of the American Oriental Society. Vol. 70. No. 4. P. 243-259.

Robinson R.H. 1976. Early Mādhyamika in India and China. Delhi: Motilal Banarsidass. 347 p.

Tang Yongtong 2011. (汤用制). 汉魏两晋南北朝佛教史 [Буддизм периода династий Хань, Вэй, двух Цзинь, Южных и Северных династий]. Beijing: Beijing daxuе. $563 \mathrm{p}$.

Tian Yuqing 2000. (田余庆). 东晋门阀政治. 北京: 北京大学出版社 [Политика знатных кланов Восточной Цзинь]. Beijing: Beijing daxue. 375 p.

Wang Zhongluo 2003. (王仲荤). 魏晋南北朝史 [История Вэй, Цзинь, а также Южных и Северных династий]. Beijing: Shanghai renmin chubanshe. 994 p.

Zürcher E. 2007. The Buddhist Conquest of China: the Spread and Adaptation of Buddhism in Early Medieval China. $3^{\text {rd }}$ ed. Leiden: Koninklijke Brill NV. 472 p.

\title{
MONARCHS AND CHANCELLORS OF THE EASTERN JIN ERA (317-420 AD) AND EARLY CHINESE BUDDHISM
}

\begin{abstract}
The article carries out a concrete historical analysis of the event structure associated with the activities of the court clans of the Eastern Jin Dynasty and briefly examines and analyzes the complex and little-studied problems of the historical and political process and the history of early Chinese Buddhism in the troubled era of East Jin. The author concludes that during the period of Eastern Jin there was an important shift in the religious and ideological preferences of the South Chinese elite - from Taoism to Chinese Buddhism. Taoist, Buddhist and Confucian cults served as the ideological tool of the court groups in the struggle for the key posts and resources of the South China Empire. The foundation was laid for the formation of the concept of the three teachings (San Jiao). All this allows us to characterize this dynasty as a pseudo-monarchy or military-monarchist dictatorship.
\end{abstract}

Keywords: South China, Eastern Jin (317-420 AD), court clans, early Chinese Buddhism 